\title{
Estimation of permanent displacements of the Tehri dam in the Himalayas due to future strong earthquakes
}

\author{
ANIRUDDHA SENGUPTA \\ Department of Civil Engineering, Indian Institute of Technology, \\ Kharagpur 721 302, West Bengal \\ e-mail: Sengupta@civil.iitkgp.ernet.in
}

MS received 14 January 2001; revised 9 December 2009; accepted 1 May 2010

\begin{abstract}
The objective of this paper is to estimate permanent displacements of Tehri dam due to an earthquake of magnitude $M_{w}=8 \cdot 5$, the occurrence of which has a high probability in the region, and for an earthquake of magnitude $M_{w}=7 \cdot 0$, for which the dam has been currently designed. A two-dimensional finite element analysis and five different semi-empirical and empirical methods, like, Seed and Makdisi's method, Newmark's double integration method, Jansen's method, Swaisgood's method and Bureau's method have been utilized to study the probable dynamic behaviour of the dam and their results are compared to get a range of values within which, the permanent displacement of the dam, is estimated to lie. The present study shows that the predicted displacements due to an earthquake of magnitude $M_{w}=7.0$ are significant but not enough to compromise the safety of the dam. However, the displacements predicted for an earthquake of magnitude $M_{w}=8.5$ are quite high and might cause rupture of filter zones. The maximum deformations ( $755 \mathrm{~cm}$ for $M_{w}=8.5$ and $43 \mathrm{~cm}$ for $M_{w}=7.0$ ) are predicted by Seed and Makdisi's method while the minimum deformations $\left(14 \mathrm{~cm}\right.$ for $M_{w}=8.5$ and $2.5 \mathrm{~cm}$ for $M_{w}=7.0$ ) are computed by Jansen's method.
\end{abstract}

Keywords. Tehri dam; dynamic behaviour; displacement; earthquake; finite element analysis.

\section{Introduction}

Estimating permanent displacements that an earthen/rockfill embankment dam will undergo during an earthquake shaking is a very difficult task. The effort is made more difficult by the myriad of factors that are involved and lack of reliable field data. The ground vibrations at a site are unique to the particular earthquake causing them and to the site-specific conditions existing at the dam. The characteristics of a dam, such as, type of construction, structural height, upstream and downstream reservoir levels affect the response of the structure (USBR, 1989). Significant amount of work has been done over the years towards understanding the seismic behaviour of earth and rockfill dams starting with the fifth Rankine lecture by Newmark (Newmark 1965). Newmark (1965) and Seed (1966) were the first to propose methods of 
analysis for predicting the permanent displacements of dams subjected to earthquake shaking. Seed \& Martin (1966), Ambraseys \& Sarma (1967), Lin \& Whitman (1983) used shear beam analysis to study the dynamic response of embankment dams. The failure of Sheffield Dam (Seed et al 1969) and San Fernando Dam (Seed 1973) prompted Seed and other researchers to further review and modify the Newmark's method to study seismic stability of earth and rockfill dams (Sarma 1975; Serff et al 1976; Makdisi \& Seed 1978; Seed 1979; Seed 1981; Romo \& Resendiz 1981; Resendiz \& Romo 1982; Abdel-Ghaffar \& Scott 1978; AbdelGhaffar \& Scott 1979; Lin \& Whitman 1986; Elgamal et al 1990; Yan 1991; Gazetas \& Dakoulas 1992; Bray \& Travasarou 2007). Newmark treated the sliding mass as a rigid body. However, Seed and other researchers recognized that an embankment dam responds as a flexible structure and introduced a technique to estimate the amplification of ground motions to the crest of the dam. The analysis is then based on estimating the maximum peak crest acceleration and maximum acceleration of the potentially sliding mass. From where, yield acceleration of the sliding mass and ultimately displacement of the crest of the dam are estimated. Around the same time, some of the researchers (Jansen 1990; Swaisgood 1995; Bureau 1997) were trying to tackle the problem from a completely different angle. Their methods are empirical in nature and based on statistical analyses of data from a limited number of failure case histories. These methods are very simplistic in nature and often used by dam designers to gain confidence about the results obtained from more rigorous analyses. With the advent of fast computers and significant progress in nonlinear material modelling and testing, the embankment dams are increasingly being studied by finite element and finite difference methods with advanced nonlinear material models (Zienkiewicz et al 1980; Vrymoed 1981; Mejia et al 1982; Prevost et al 1985; Gazetas \& Uddin 1994; Martin et al 1993; Martin \& Sengupta 1994; Sengupta \& Martin 1996; Sengupta \& Martin 1997; Li et al 2008). In some cases, experts (Mejia \& Seed 1983; Elgamal \& Abdel-Ghaffar 1987; Gazetas \& Dakoulas 1992; Papalou \& Bielak 2004) have even recommended three-dimensional analysis to include effects of canyon, and other site-specific geometric irregularities on the dynamic stability of a dam. The sophisticated analytical tools, like boundary elements, finite element and finite difference methods are the most recommended method. However, realistic deformation values may be expected from such advanced analyses only when the material models and the material parameters are capable of accurately simulating real life scenario. Though significant progress has been made in modelling material behaviour still most of the material models perform poorly when comes to reality check. Though three-dimensional analyses are very common in concrete dams, it is not that often done for earth and rockfill dams. The reason is that these natural materials are highly nonhomogeneous in nature. Their properties depend on lift size, water content, compaction effort, etc., which often can not be properly quantified. Also often the exact direction of the ground motion in case of a future earthquake can not be properly determined in a dam which has not previously experienced any such event. Even with all these limitations, dynamic finite element analysis of embankment dam is recommended for proper evaluation of its seismic safety.

In order to meet the huge demand for power by the industries and ever increasing population, several hydro-power projects are coming up in the Himachal Pradesh, Sikkim, Bhutan and Assam. Thus there is a good reason to have a fresh look into the Himalayan seismicity and the performance of these new as well as old dams located in the Himalaya regions. This paper reviews some of the simplified methods to estimate seismic displacements of a high rockfill dam and compares their performance with that obtained from a 2-D nonlinear finite element analysis. In this study a high rockfill dam, called Tehri dam nested in the Garhwal Himalaya is chosen. The earthquake-induced displacement of the dam is studied by various established 


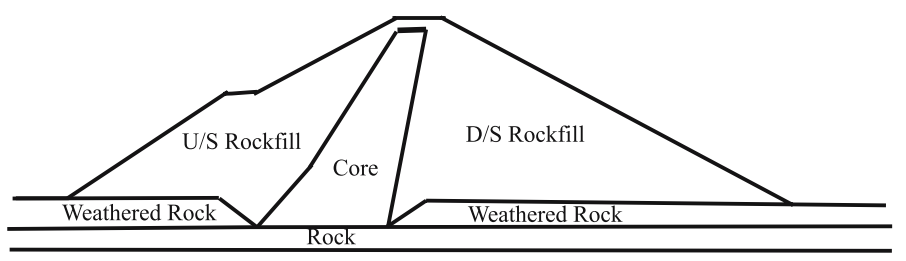

Figure 1. Typical cross-section of Tehri dam.

methods when subjected to two hypothetical earthquakes, one with magnitude $\left(M_{w}\right) 7 \cdot 0$ and peak ground acceleration (PGA) of $0.23 \mathrm{~g}$ and another with magnitude $\left(M_{w}\right) 8.5$ and PGA of $0.45 \mathrm{~g}$.

\section{Tehri dam}

The Tehri dam is located at $30^{\circ} 28^{\prime}$ North and $78^{\circ} 30^{\prime}$ East, very near the town of Tehri in the Garhwal region of Uttaranchal in India. The rockfill dam is built on the Bhagirathi River, which flows in a deep, nearly triangular canyon at the site. The dam, conceived in 1949 and sanctioned in 1972, is the fifth highest dam in the world. It is $260.5 \mathrm{~m}$ in height at the deepest point. The crest is $20 \mathrm{~m}$ wide and spans $574 \mathrm{~m}$ across the valley. The base width of the dam in upstream-downstream direction is nearly 1 kilometer. A $9.5 \mathrm{~m}$ of freeboard is provided at the crest. The upstream slope of the dam is $2 \cdot 5(\mathrm{H}): 1(\mathrm{~V})$. The downstream slope is $2(\mathrm{H}): 1(\mathrm{~V})$. The rockfill dam has an inclined impervious core made of clayey materials and upstreamdownstream shells of graded gravel topped with blasted rocks. A detail description of the dam is given by Thatte (Thatte 1992). Figure 1 shows a typical cross-section of the dam assumed in the present analyses. The locations of the slide surfaces are shown in figure 2. Almost no published information is available on the in situ strengths of the dam materials. Based on past experiences of similar dams and the description of the dam materials given by Thatte, the in situ drained strengths of the dam materials have been estimated. The nonlinear properties (shear modulus and damping) of the dam materials utilized for the shear beam analyses are adopted from Seed et al (1986). Table 1 shows the drained strengths of the dam materials assumed in the present analyses.

\section{Seismicity at Tehri dam}

A number of large magnitude $\left(M_{w}>7\right)$ earthquakes have occurred along the Himalayan mountain belt, four of which (1897 Assam earthquake $\left(M_{S}>8 \cdot 7\right)$, 1905 Kangra earthquake

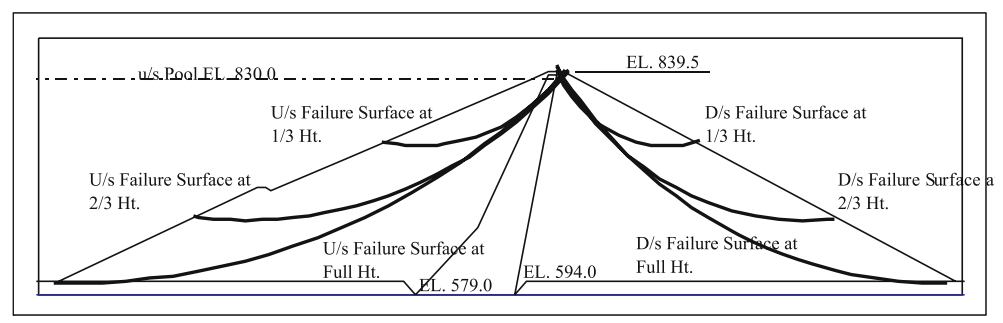

Figure 2. Location of $U / s$ and $D / s$ failure surfaces. 
Table 1. Material strength parameters.

\begin{tabular}{|c|c|c|c|c|}
\hline \multirow[b]{2}{*}{ Zones of dam } & \multicolumn{2}{|c|}{ Densities in $\mathrm{t} / \mathrm{m}^{3}$} & \multirow[b]{2}{*}{ Cohesion, $c^{\prime}$} & \multirow[b]{2}{*}{ Friction Angle, $\phi$} \\
\hline & Moist & Saturated & & \\
\hline U/S Rock fill & 1.92 & $2 \cdot 16$ & 0.00 & $40 \cdot 00$ \\
\hline D/S Rock fill & $2 \cdot 08$ & $2 \cdot 24$ & 0.00 & $35 \cdot 00$ \\
\hline Core & 1.86 & 2.00 & 0.00 & 30.00 \\
\hline Rock, Weather Rock & & $2 \cdot 30$ & 0.00 & $45 \cdot 00$ \\
\hline
\end{tabular}

$\left(M_{S}>8.6\right), 1934$ Bihar earthquake $\left(M_{S}=8.4\right)$ and 1950 Assam earthquake $\left.\left(M_{S}=8.7\right)\right)$ had magnitude greater than 8 (Richter 1958). Many eminent researchers in this field (Khattri 1993; Bilham \& Szeliga 2008; Feldl \& Bilham 2006; Rajendran \& Rajendran 2005) believe that strain is persistently building up along the Himalayan collision arc by the convergence of the Indian and Asian plates. This strain is released by great earthquakes only. However, the four great earthquakes in the past have ruptured only 200 to $450 \mathrm{~km}$ of the plate boundary, leaving unruptured sections in between called seismic gaps. The unruptured section of Himalaya between the rupture zones of Kangra \& Bihar earthquakes is called central Himalayan seismic gap. The Tehri dam is located within this seismic gap. There has been considerable controversy concerning the seismic intensity to which the Tehri dam may be subjected to as no great earthquake have occurred in this gap region within the past 200 years (Gaur 1993; Iyengar 1993). The above researchers believe that the earthquakes in the past two centuries have not been representative of infrequent great $\left(M_{w}>8\right)$ plate boundary event that could occur. It is reasoned that recent earthquakes may have responded to different elastic driving forces from those that drove the mega quakes of medieval times. It is suspected that an alternate source of energy to cause a great earthquake exists in the form of elastic and gravitational energy and is stored in flexure of the Indian plate, and is now sufficiently mature to sustain a mega quake of $M_{w}>8$ (Ambraseys \& Jackson 2003; Ambraseys \& Bilham 2000).

In this paper, the seismic behaviour of the Tehri dam has been studied for two earthquake motions. The first one is an $M_{w}=7, \mathrm{PGA}=0.23 \mathrm{~g}$ earthquake for which the dam has been designed (Thatte 1992). The second motion is for an $M_{w}=8 \cdot 5, \mathrm{PGA}=0.45 \mathrm{~g}$ hypothetical earthquake. This second motion represents MCE of the region according to some experts and initially recommended by THDC (1990) and High Level Committee of Experts (1990). There are considerable controversies between the experts regarding the validity of these motions. The proper way of coming up with a motion is to establish seismic sources within $500 \mathrm{~km}$ and their maximum potential, and perform probabilistic seismic hazard analysis. But this is neither the objective nor within the scope of the present work.

\section{Selection of response spectra and ground motion for present study}

In absence of any site-specific data, the response spectra and the corresponding ground motions for the Tehri dam design were developed synthetically. These are given by Thatte (1992) and Finn (1993). In the present study, the artificially generated response spectra given by Thatte (1992) have been utilized for the simplified analyses. Figure 3 shows the response spectra corresponding to $5 \%, 7 \%, 10 \%$, and $15 \%$ damping and scaled to $0.23 \mathrm{~g}$ PGA. For the $0.45 \mathrm{~g}$, the same response spectra have been arithmetically scaled to $0.45 \mathrm{~g}$. One of the 


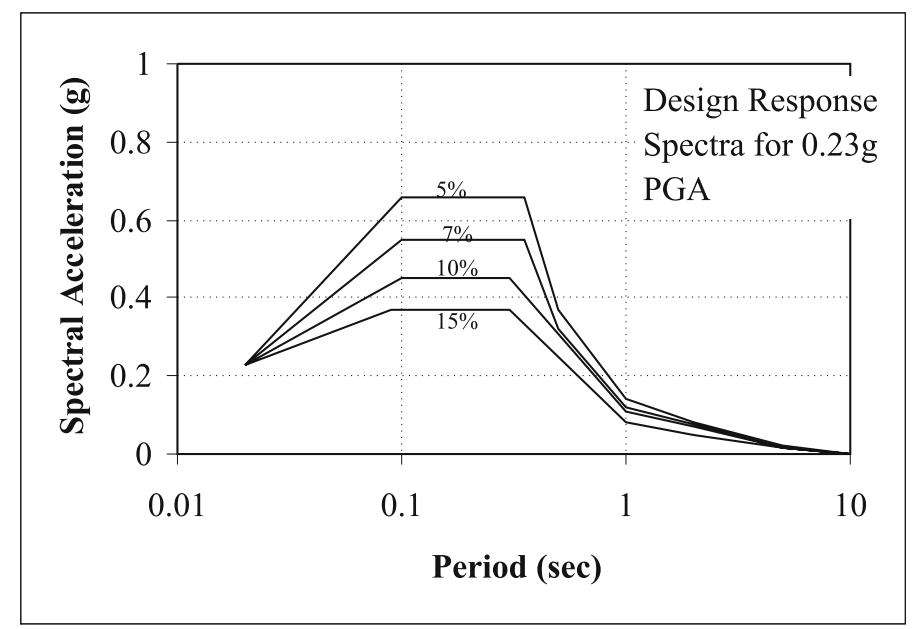

Figure 3. Design response spectra for $0.23 \mathrm{~g}$ PGA at 5, 7, 10 and $15 \%$ of critical damping.

advantages of using the same response spectra as those proposed by Thatte is that the displacements from the present study can be compared with the past theoretical study reported by him (Thatte 1992).

The finite element study of the dam requires a representative ground motion to be specified. In absence of any data from the region, Thatte (1992) and Finn (1993) have utilized artificial ground motion. In the present study, a number of earthquake motions are reviewed and 09/19/1985 Michoacan Mexico City Earthquake ( $M_{w}=7 \cdot 6$, PAPANOA, N90W component) motion is selected based on its PGA, frequency content, focal depth, etc. The selected motion is a far field rock motion with focal depth of $20 \mathrm{~km}$ and epicentral distance of $83 \mathrm{~km}$. Most of the Himalayan earthquakes have similar shallow focal depth (Khattri 1993). The maximum acceleration, $a$, maximum velocity, $v$, maximum displacement, $d$, and predominant period are $221.96 \mathrm{~cm} / \mathrm{s}^{2}, 5.01 \mathrm{~cm} / \mathrm{s}, 0.62 \mathrm{~cm}$, and $0.14 \mathrm{~s}$, respectively for the selected motion. Thus, the value of $v^{2} / a d$ is given by 0.18 which lies between 0.06 and 0.4 as recommended by Newmark (1965). The value of $v / a$ is found to be 0.023 which is less than $0 \cdot 1$, confirming that it is a rock motion (Newmark 1965). Figure 4 shows a comparison between the response spectra (at 0\% damping) of the selected motion and that given by Thatte (1992). The figure also confirms suitability of the selected motion for the present case. The selected motion is arithmetically scaled to $0.45 \mathrm{~g}$ to study dam behaviour during a $M_{w}=8.5$ earthquake.

\section{Response spectra analyses of Tehri dam}

Earth dams are large 3-D structures constructed from inelastic and non-homogeneous materials. Consequently, the computation of natural frequencies and modes of vibration is extremely difficult and as a result, existing theories and analyses of earth dams make many simplifying assumptions (Abdel-Ghaffar \& Scott 1978). The approach selected for this study consisted of performing a response spectrum analysis of the dam modelled as a shear beam with variable stiffness (triangular shape). The assumed response spectra at 5\%,7\%,10\% and $15 \%$ of critical damping for the $M_{w}=7$, PGA $=0.23 \mathrm{~g}$ earthquake are taken from Thatte (1992) and shown in figure 3 . The response spectra for the $M_{w}=8.5, \mathrm{PGA}=0.45 \mathrm{~g}$ earthquake are 


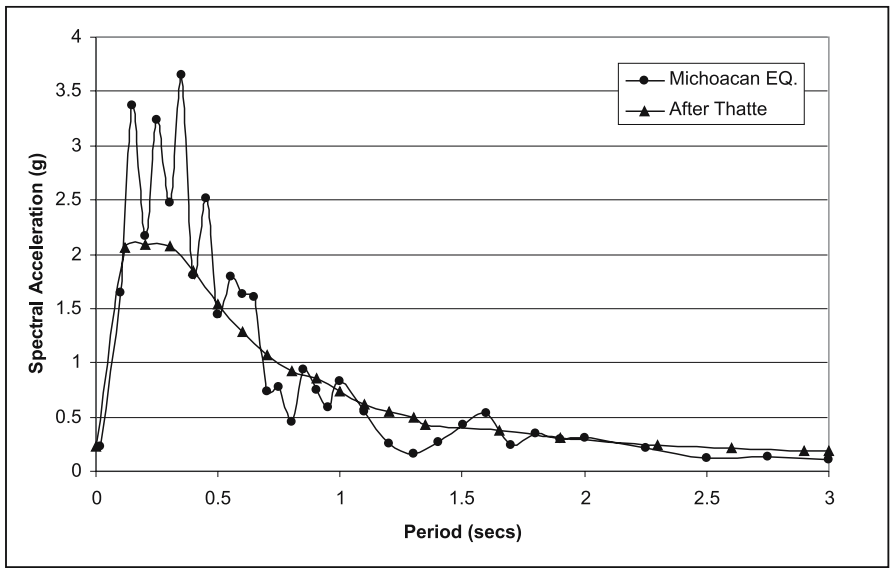

Figure 4. Comparison of response spectra given by Thatte (1992) and that of Michoacan earthquake of 1985 .
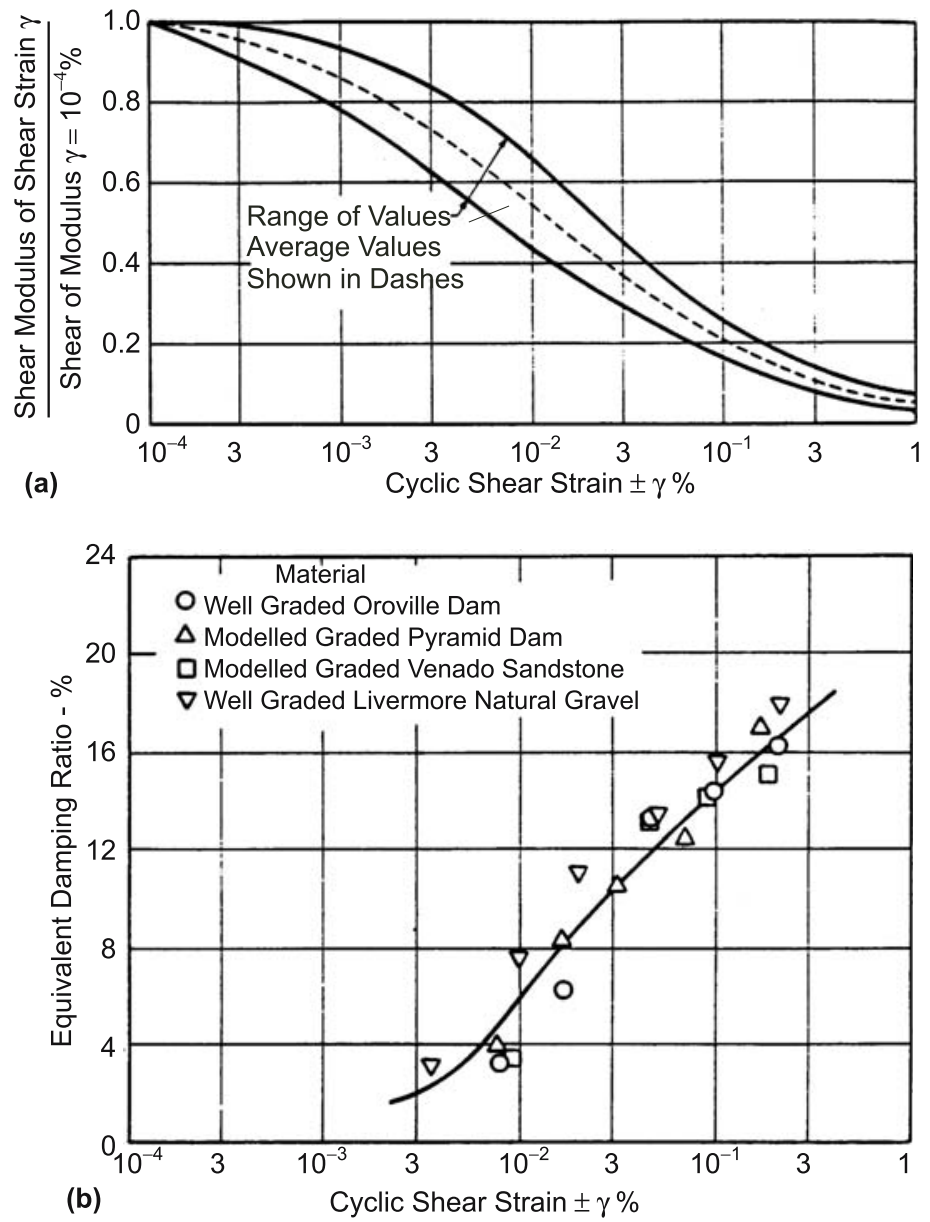

Figure 5. Dependency of stiffness and damping of gravelly soils on strain level (Seed et al 1986). 
Table 2. Results of response spectrum analysis.

\begin{tabular}{lcc}
\hline & \multicolumn{2}{c}{ Magnitude of earthquake $\left(M_{w}\right)$} \\
\cline { 2 - 3 } & 7.0 & 8.5 \\
\hline Maximum crest acceleration, $a_{\max }$ & $0.62 \mathrm{~g}$ & $0.96 \mathrm{~g}$ \\
Predominant period, $T_{o}$ & $1.10 \mathrm{sec}$ & $1.10 \mathrm{sec}$ \\
Average equivalent strain & $0.015 \%$ & $0.03 \%$ \\
Strain compatible damping & $8 \%$ & $9 \%$ \\
\hline
\end{tabular}

obtained by arithmetic scaling of the same spectral acceleration for the $0.45 \mathrm{~g}$ PGA. The strain dependency of stiffness and damping of soils causes nonlinearity between the level of excitation and the level of dynamic response. The shear beam procedure is adopted for the dam materials (rockfill) by following an equivalent linear approach that amounts to calculating dynamic soil properties iteratively until those properties are compatible with the calculated strain level. The curves used in the analysis to characterize the dependency of stiffness and damping of gravelly materials on strain level are proposed by Seed et al (1986) and shown in figure 5. Convergence to strain-compatible properties of the constitutive dam materials is achieved within two and three cycles of iterations for the 7.0 and 8.5 magnitude earthquakes, respectively. The results of the response spectrum analyses for the two selected earthquake motions in terms of maximum crest acceleration, natural period of the dam and strain compatible damping are shown in table 2 . The amplification of the motion through the dam is found to be 2.69 for $M_{w}=7$ and $2 \cdot 1$ for the $M_{w}=8.5$ earthquakes.

\section{Determination of permanent displacements by simplified method}

\subsection{Seed and Makdisi's method}

The simplified procedure developed by Makdisi \& Seed (1978) follows the premise that permanent displacements take place whenever the rigid body acceleration, $K_{\max }$, of a potential sliding mass exceeds the yield acceleration, $K_{y}$, for that mass. The yield acceleration is determined by performing a series of pseudo-static analyses. Makdisi and Seed have related the rigid body acceleration for various sliding masses to the peak acceleration at the crest of the dam and to the depth of the sliding mass. Once the yield accelerations have been determined, the permanent displacements, $U$, for a given ratio of $K_{y} / K_{\max }$, can be obtained, since it is only a function of the magnitude of the earthquake, the fundamental period of the dam and the rigid body acceleration.

The yield acceleration, $K_{y}$ is defined as that average acceleration which produces a horizontal inertia force on a potential sliding mass to yield a factor of safety of unity and thus causing it to experience permanent displacements. Yield accelerations are determined for three potential sliding masses on the upstream slope and three sliding masses on the downstream slope of Tehri dam. The locations of the slide surfaces are shown in figure 2 . The upstream and downstream water levels are assumed at $830 \mathrm{~m}$ (maximum normal operating pool) and $594 \mathrm{~m}$, respectively during an earthquake. The strength parameters for the dam and foundation materials for the stability analyses are given in table 1 . The stability analyses are performed according to Simplified Bishop's method. Table 3 summarizes the results of the static stability analysis and the values of yield acceleration, $K_{y}$ for all the six cases. 
Table 3. Yield accelerations.

\begin{tabular}{lccc}
\hline Zones of dam & Location of surface & $\begin{array}{c}\text { Factor of safety } \\
(F S) \text { in static case }\end{array}$ & $\begin{array}{c}\text { Yield acceleration }\left(K_{y}\right) \\
\text { corresponding to a } F \text { of } 1\end{array}$ \\
\hline Downstream & 1/3 height & 1.61 & 0.225 \\
Slope & 2/3 height & 1.51 & $0 \cdot 191$ \\
& Full height & 1.49 & $0 \cdot 182$ \\
Upstream & 1/3 height & $2 \cdot 37$ & $0 \cdot 281$ \\
Slope & 2/3 height & 2.47 & $0 \cdot 255$ \\
& Full height & $2 \cdot 35$ & 0.228 \\
\hline
\end{tabular}

Makdisi and Seed showed that a unique relationship exists between the yield acceleration, $K_{y}$, the depth of slip surface, $y / h$, and the ratio of the maximum rigid body acceleration, $K_{\max }$ to the maximum crest acceleration, $a_{\max }$. The relationship shown in figure 6 is used to determine the values of, $K_{\max }$, for each sliding mass under the design motion. The upper bound curve is utilized in the present analysis.

The values of $K_{\max }$ and $K_{y} / K_{\max }$ for all the cases are shown in table 4 . The horizontal displacement, $U$, for each of the sliding masses is estimated from the curves shown in figure 7 . These curves (adopted from Makdisi \& Seed 1978) relate displacement, $U$, with the magnitude $\left(M_{w}\right)$ of earthquake, $K_{y} / K_{\max }$, and the period of the dam, $T_{o}$. The displacements of the Tehri dam thus obtained for $M_{w}=7.0$ and $M_{w}=8.5$ magnitude earthquakes are shown in table 5 .

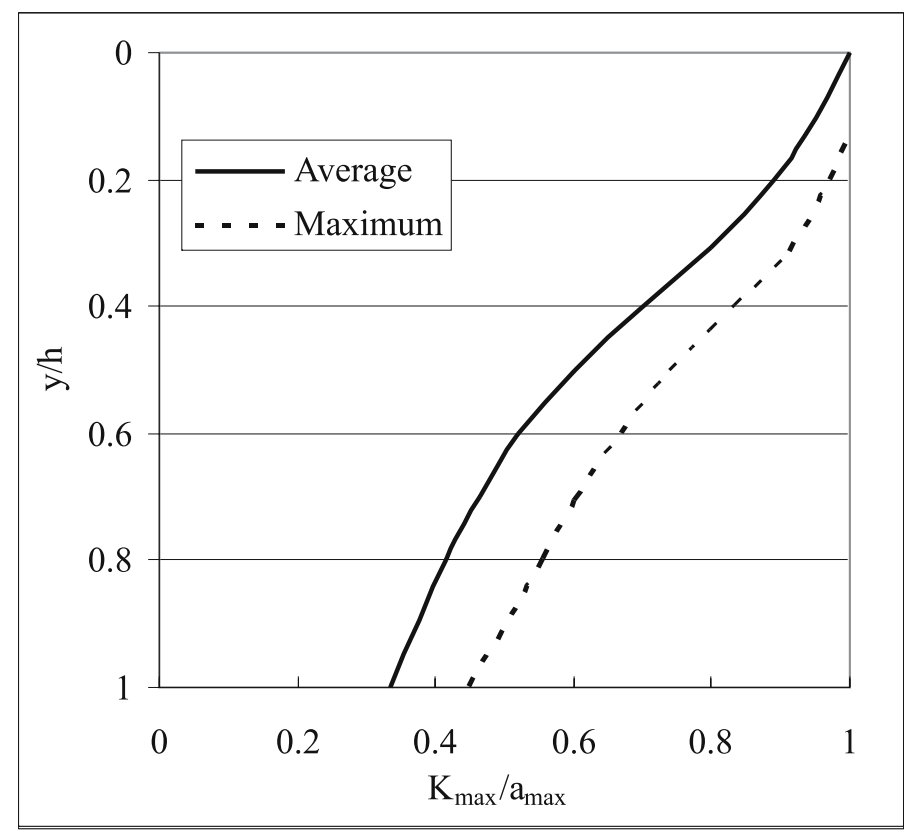

Figure 6. Relationship between $y / h$ and $K_{\max } / a_{\max }$ (Makdisi \& Seed 1978). 
Table 4. Rigid body maximum acceleration.

\begin{tabular}{|c|c|c|c|c|c|c|c|c|c|}
\hline \multirow{3}{*}{$\begin{array}{l}\text { Location } \\
\text { of sliding } \\
\text { surface }\end{array}$} & \multirow{3}{*}{$\begin{array}{c}\text { Depth } \\
y / H\end{array}$} & \multicolumn{4}{|c|}{$M_{w}=7 \cdot 0$} & \multicolumn{4}{|c|}{$M_{w}=8.5$} \\
\hline & & \multicolumn{2}{|c|}{ Upstream } & \multicolumn{2}{|c|}{ Downstream } & \multicolumn{2}{|c|}{ Upstream } & \multicolumn{2}{|c|}{ Downstream } \\
\hline & & $K_{\max }(\mathrm{g})$ & $K_{y} / K_{\max }$ & $K_{\max }(\mathrm{g})$ & $K_{y} / K_{\max }$ & $K_{\max }(\mathrm{g})$ & $K_{y} / K_{\max }$ & $K_{\max }(\mathrm{g})$ & $K_{y} / K_{\max }$ \\
\hline 1/3 Height & $0 \cdot 33$ & 0.57 & 0.50 & 0.57 & 0.40 & 0.88 & 0.32 & $0 \cdot 88$ & $0 \cdot 26$ \\
\hline 2/3 Height & $0 \cdot 66$ & 0.41 & 0.62 & 0.41 & 0.47 & 0.64 & 0.40 & 0.64 & $0 \cdot 30$ \\
\hline Full Height & 1.00 & $0 \cdot 29$ & 0.78 & $0 \cdot 29$ & 0.62 & 0.45 & 0.50 & 0.45 & 0.40 \\
\hline
\end{tabular}

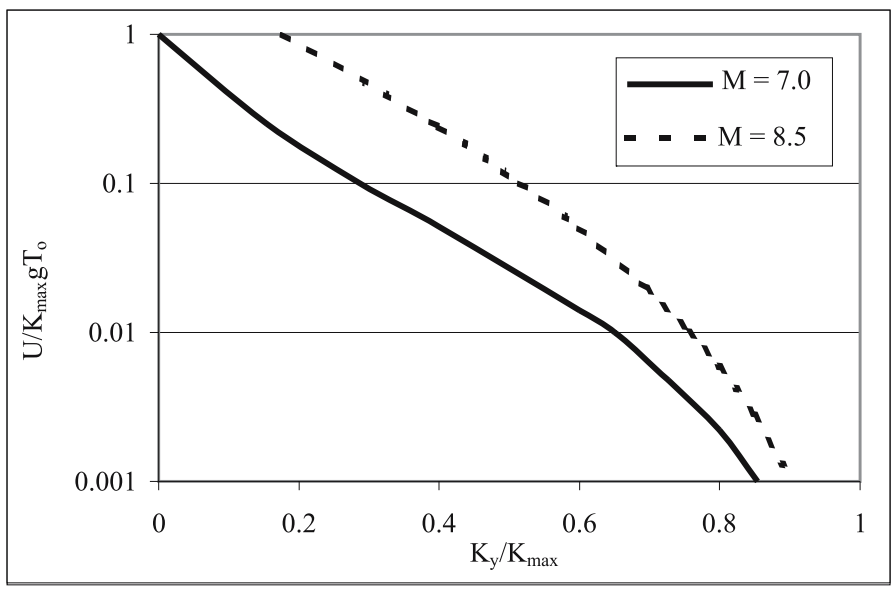

Figure 7. Relationship between $K_{y} / K_{\max }$ and $U / K_{\max } g T_{o}$ (Makdisi \& Seed 1978).

Table 5. Permanent displacements by Makdisi \& Seed's Procedure.

\begin{tabular}{|c|c|c|c|c|c|c|}
\hline \multirow{3}{*}{$\begin{array}{l}\text { Surface } \\
\text { location }\end{array}$} & \multicolumn{6}{|c|}{ Magnitude of earthquake, $M_{w}=7 \cdot 0$} \\
\hline & \multicolumn{3}{|c|}{ Upstream } & \multicolumn{3}{|c|}{ Downstream } \\
\hline & $K_{y} / K_{\max }$ & $U /\left[K_{\max } \cdot g \cdot T_{o}\right]$ & $U(\mathrm{cms})$ & $K_{y} / K_{\max }$ & $U /\left[K_{\max } \cdot g \cdot T_{o}\right]$ & $U(\mathrm{cms})$ \\
\hline 1/3 Height & 0.497 & $0 \cdot 045$ & 27.44 & $0 \cdot 398$ & 0.070 & $42 \cdot 68$ \\
\hline 2/3 Height & $0 \cdot 622$ & $0 \cdot 015$ & $6 \cdot 64$ & 0.466 & $0 \cdot 060$ & $26 \cdot 54$ \\
\hline \multirow[t]{3}{*}{ Full Height } & $0 \cdot 781$ & $0 \cdot 005$ & 1.57 & 0.623 & $0 \cdot 015$ & $4 \cdot 73$ \\
\hline & \multicolumn{6}{|c|}{ Magnitude of earthquake, $M_{w}=7 \cdot 0$} \\
\hline & \multicolumn{3}{|c|}{ Upstream } & \multicolumn{3}{|c|}{ Downstream } \\
\hline $\begin{array}{l}\text { Surface } \\
\text { location }\end{array}$ & $K_{y} / K_{\max }$ & $U /\left[K_{\max } \cdot g \cdot T_{o}\right]$ & $U(\mathrm{cms})$ & $K_{y} / K_{\max }$ & $U /\left[K_{\max } \cdot g \cdot T_{o}\right]$ & $U(\mathrm{cms})$ \\
\hline 1/3 Height & $0 \cdot 321$ & $0 \cdot 600$ & $566 \cdot 53$ & 0.257 & $0 \cdot 800$ & $755 \cdot 37$ \\
\hline 2/3 Height & 0.402 & $0 \cdot 400$ & 275.46 & $0 \cdot 301$ & $0 \cdot 650$ & $445 \cdot 40$ \\
\hline Full Height & 0.504 & $0 \cdot 100$ & $48 \cdot 77$ & 0.403 & $0 \cdot 350$ & $170 \cdot 71$ \\
\hline
\end{tabular}




\subsection{Double integration method}

This method of computing the earthquake-induced deformation is based on the sliding wedge analogy proposed by Newmark (1965). According to this method, sliding of a failure mass occurs whenever the inertia of the mass exceeds the frictional resistance along the sliding surface. The frictional resistance is characterized by the yield acceleration, $K_{y}$. Relative displacements are calculated by double integration of the difference between mass acceleration and yield acceleration.

Since dynamic stresses and accelerations are directly related, it is surmised that it is possible to replace an actual acceleration history by a number of cycles of sinusoidal wave form of constant amplitude in the same manner as it is customary to replace a time history of stresses by a number of cycles of stresses of constant amplitude. Following the procedure developed by Seed \& Idriss (1971) to convert an actual irregular stress time history into repetition of several stress cycles of constant amplitude, the equivalent acceleration time history is constructed. The $M_{w}=8.5$ earthquake is modelled by 26 cycles of identical full sinusoidal waves. The average value of acceleration amplitude, $a_{\mathrm{avg}}$ is calculated as $2 / 3$ of PGA and found to be $0 \cdot 3 \mathrm{~g}$. The $7 \cdot 0$ magnitude earthquake is modelled by 15 cycles of identical full sinusoidal waves. The average value of acceleration amplitude, $a_{\mathrm{avg}}$, for this case is found to be $0 \cdot 15 \mathrm{~g}$. The equivalent time history of acceleration may then be represented by a sine wave given by:

$$
K(t)=a_{\mathrm{avg}} \operatorname{Sin}\left(2 \cdot \pi \cdot \frac{t}{T}\right) .
$$

The calculated displacements are a function of $T$, period of the acceleration time history. The longer the period, the larger are the computed displacements. The period of the motion is a function of the foundation conditions, magnitude of the earthquake, distance to the source and intensity of shaking. For embankment dams, it typically lies between 0.1 second and 1.0 second.

For the $M_{w}=7.0$ earthquake, the yield accelerations for the upstream and downstream slopes are greater than the average value of acceleration amplitude, $a_{\mathrm{avg}}$ of $0.15 \mathrm{~g}$. In other word, the factors of safety for sliding of both the slopes of Tehri dam are greater than unity under $M_{w}=7.0$ magnitude earthquake. Thus the displacements of both the slopes of Tehri dam are negligible for the $M_{w}=7.0$ earthquake. However, this is not the case for the $M_{w}=8.5$ earthquake. The $M_{w}=8.5$ earthquake is modelled by 26 cycles of identical full sinusoidal waves. The total displacement is computed by multiplying the displacement at the end of each cycle by the total number of cycles (26). It is assumed that the displacement is triggered at time, $t_{1}$ when the acceleration of the base exceeds the yield acceleration, $K_{y}$. After time, $t_{1}$, the resistance to displacement, expressed in terms of $K_{y}$, did not diminish after displacement has been initiated. It is assumed that the negative portion of the wave follows directly after the positive one. The area under the negative portion is that required to bring the relative velocity back down to zero before the start of the next cycle. Figure 8 shows the whole scheme graphically.

As may be seen from figure $8, t_{1}$ and $t_{2}$ are the limits within which the ground acceleration $(K)$ exceeds yield acceleration $\left(K_{y}\right)$. The values of the limits $t_{1}$ and $t_{2}$ are computed for both the cases by solving the following equations:

$$
\begin{gathered}
K\left(t_{1}\right)-K_{y}=0, \\
K\left(t_{2}\right)-K_{y}=0 .
\end{gathered}
$$



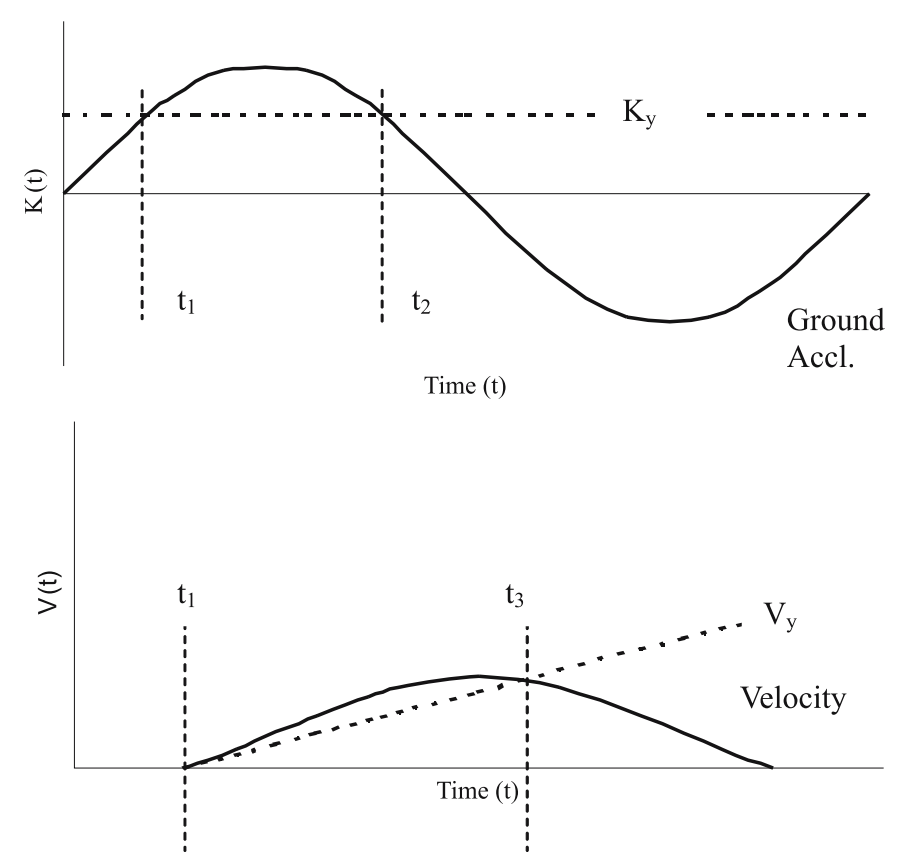

Figure 8. One cycle of ground motion and its velocity component.

The predominant period of the dam is $1.1 \mathrm{sec}$ from response spectra analysis. The values of $t_{1}$ and $t_{2}$ at this period of motion are found to be $0.137 \mathrm{sec}$ and $0.363 \mathrm{sec}$, respectively for the upstream slope and $0 \cdot 104 \mathrm{sec}$ and $0.396 \mathrm{sec}$, respectively for the downstream slope of the dam.

In figure $8, t_{3}$ is the time at which mass velocity, $V$, equals resisting velocity, $V_{y}$. The value of $t_{3}$ can be obtained by solving the following equation:

$$
\int_{t_{1}}^{t_{3}} K(t) d t-\int_{t_{1}}^{t_{3}} K_{y} d t=0
$$

The value of $t_{3}$ is $0.482 \mathrm{sec}$ for the upstream slope and $0.558 \mathrm{sec}$ for the downstream slope of the Tehri dam.

An expression for the resisting velocity, $V_{y}$ can be obtained, as follows, by integrating the yield acceleration, $K_{y}$ :

$$
V_{y}(t)=K_{y} \cdot t-K_{y} \cdot t_{1}
$$

An expression for mass velocity, $V$, is obtained by integrating equation (1) as follows:

$$
V(t)=-a_{\mathrm{avg}} \frac{T}{2 \cdot \pi} \cdot \operatorname{Cos}\left(\frac{2 \cdot \pi \cdot t}{T}\right)+a_{\mathrm{avg}} \frac{T}{2 \cdot \pi} \cdot \operatorname{Cos}\left(\frac{2 \cdot \pi \cdot t_{1}}{T}\right) .
$$

The relative displacement, $d$, of the dam at the end of each cycle is then computed by integrating the difference between the mass velocity and the yield velocity as follows:

$$
d=\int_{t_{1}}^{t_{3}}\left(V(t)-V_{y}(t)\right) d t
$$




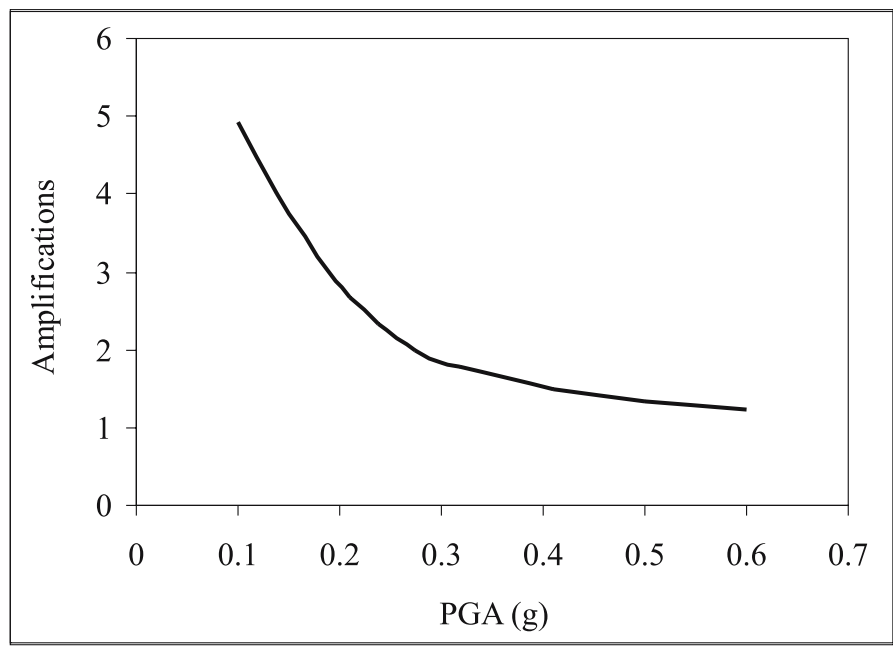

Figure 9. Amplification at the embankment dams during an earthquake.

According to the double integration method, total relative displacement of the Tehri dam at the end of an $M_{w}=8.5$ earthquake is estimated to be between $52.8 \mathrm{~cm}$ for the upstream slope and $147.4 \mathrm{~cm}$ for the downstream slope.

\subsection{Jansen's method}

Jansen (1990) developed the following empirical relationship between earthquake magnitude, $M$, the maximum crest or near crest acceleration, $K_{m}$, the yield acceleration, $K_{y}$, and the total settlement at the crest, $U$ :

$$
U=\left[48 \cdot 26(M / 10)^{8}\left(K_{m}-K_{y}\right)\right] / \sqrt{ } K_{y} .
$$

The value of amplification at the crest $\left(K_{m}\right)$ in the above equation can be obtained from figure 9.

This method does not consider the height of dam directly in the displacement estimate. The total settlement at the crest, $U$, at different surface location are shown in table 6 . The

Table 6. Estimate of total settlement of Tehri dam from Jansen's method.

\begin{tabular}{|c|c|c|c|c|c|c|}
\hline \multirow{2}{*}{$\begin{array}{l}\text { Value of } \\
\left.K_{m} \text { (in } \mathrm{g}\right)\end{array}$} & \multirow{2}{*}{$\begin{array}{c}\text { Magnitude of } \\
\text { earthquake }\left(M_{w}\right)\end{array}$} & \multirow{2}{*}{$\begin{array}{l}\text { Location of critical } \\
\text { sliding surface }\end{array}$} & \multicolumn{2}{|c|}{ Upstream slope } & \multicolumn{2}{|c|}{ Downstream slope } \\
\hline & & & $K_{y}(\mathrm{~g})$ & $U(\mathrm{cms})$ & $K_{y}(\mathrm{~g})$ & $U(\mathrm{cms})$ \\
\hline \multirow{4}{*}{$0 \cdot 56$} & & 1/3 Height & $0 \cdot 281$ & 1.45 & $0 \cdot 225$ & 1.95 \\
\hline & $7 \cdot 0$ & 2/3 Height & $0 \cdot 255$ & 1.66 & $0 \cdot 191$ & $2 \cdot 34$ \\
\hline & & Foundation & $0 \cdot 228$ & 1.93 & $0 \cdot 182$ & $2 \cdot 45$ \\
\hline & & 1/3 Height & $0 \cdot 281$ & 8.91 & 0.225 & $11 \cdot 51$ \\
\hline \multirow[t]{2}{*}{0.64} & $8 \cdot 5$ & 2/3 Height & $0 \cdot 255$ & $10 \cdot 03$ & $0 \cdot 191$ & $13 \cdot 50$ \\
\hline & & Foundation & 0.228 & $11 \cdot 35$ & $0 \cdot 182$ & $14 \cdot 13$ \\
\hline
\end{tabular}


above table shows that the maximum displacement estimated by Jansen's method is between $1.93 \mathrm{~cm}$ and $2.45 \mathrm{~cm}$ for $M_{w}=7$ earthquake. While the maximum displacement is estimated to be between $11.35 \mathrm{~cm}$ and $14.13 \mathrm{~cm}$ for the $M_{w}=8.5$ earthquake.

\subsection{Swaisgood's method}

Swaisgood (1995) developed a methodology to estimate earthquake-induced crest settlement based on statistical treatment of empirical information developed from a detailed review of the seismic performance of some 54 existing embankment dams. This relationship relates the crest settlement, $\Delta$ (expressed as percentage of the combined dam and alluvium thickness) to a Seismic Energy Factor (SEF), dam type (Ktyp), dam height $(\mathrm{H})$, and depth of alluvium (At) as follows:

$$
\Delta(\%)=\mathrm{SEF} \times \mathrm{Ktyp} \times \mathrm{Kdh} \times \text { Kat. }
$$

The seismic energy factor (SEF) in the above equation is dependent on the possible magnitude of earthquake (M) and peak ground acceleration (PGA) at the dam site and is expressed as:

$$
\mathrm{SEF}=e^{(0 \cdot 7168 * M+6 \cdot 405 * \mathrm{PGA}-9 \cdot 098)} .
$$

The factor Ktyp depends on the type of dam construction. Ktyp is 1.187 for earth core rockfill dams and concrete faced rockfill dams, 1.363 for earthfill dams, and 4.620 for hydraulic fill dams.

The factor Kat depends on the alluvial thickness (At) present beneath the dam. The greater the depth of alluvium, greater is the deformation in the dam. It also reflects the fact that the natural periods of vibration with deep and soft soil deposits are longer than that of rock sites with no alluvium.

$$
\text { Kat }=0 \cdot 851 * e^{(0 \cdot 00368 * \mathrm{At})} .
$$

The factor Kdh relates dam height $(\mathrm{H})$ to the settlement as follows:

$$
\mathrm{Kdh}=9 \cdot 134 * H^{-0 \cdot 437} .
$$

The above factor indicates that the higher dams settle less than smaller dams. This may be due to the fact that the resonant frequencies of shorter dams are closer to the natural frequencies of the earthquake vibrations.

Table 7 summarizes all the Swaisgood's factors and the estimated settlements of the Tehri dam for the two assumed earthquakes.

Table 7. Estimate of crest settlements at Tehri dam by Swaisgood's method.

\begin{tabular}{llccccc}
\hline $\begin{array}{l}\text { Magnitude of } \\
\text { earthquake, } M_{w}\end{array}$ & SEF & Ktyp & Kdh & Kat & $\begin{array}{c}\text { Relative } \\
\text { settlement, \% }\end{array}$ & $\begin{array}{c}\text { Crest } \\
\text { settlement, in cm }\end{array}$ \\
\hline 7.0 & 0.07 & 1.187 & 0.478 & 0.851 & 0.034 & 8.8 \\
8.5 & 0.9 & 1.187 & 0.478 & 0.851 & 0.43 & 112.0 \\
\hline
\end{tabular}




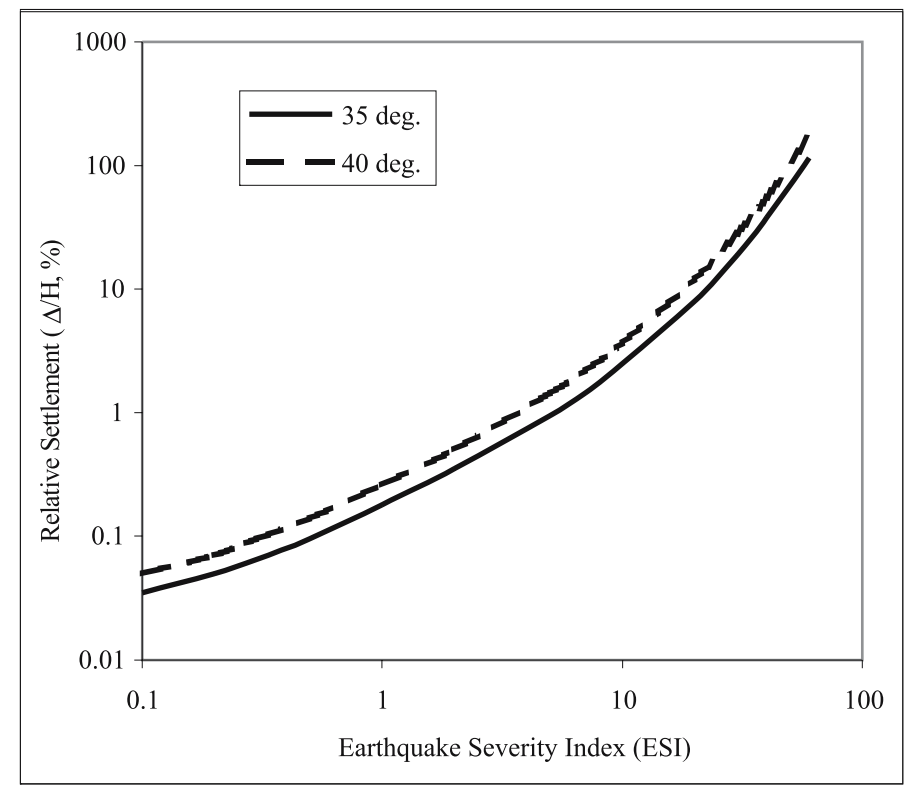

Figure 10. Relative settlement (\%) Vs. ESI (Bureau 1997).

\subsection{Bureau's method}

Bureau (1997) presented a relationship, figure 10, which relates relative crest settlement (\%) to the Earthquake Severity Index (ESI). Bureau has defined the earthquake severity index (ESI) by the following empirical equation:

$$
\mathrm{ESI}=\mathrm{PGA} *(M-4 \cdot 5)^{3} .
$$

The crest settlements of Tehri dam, as obtained by this method, are shown in table 8 .

\section{Determination of permanent deformations by finite element method}

The finite element method is known to be one of the most versatile tools available to date for the dynamic analysis of an embankment dam. However, the accuracy of the result is very much dependent on the material model chosen and on the corresponding material parameters.

Table 8. Crest settlements by Bureau's method.

\begin{tabular}{lccc}
\hline $\begin{array}{l}\text { Peak ground } \\
\text { acceleration (PGA) }\end{array}$ & $\begin{array}{c}\text { Earthquake } \\
\text { magnitude }\left(M_{w}\right)\end{array}$ & ESI & $\begin{array}{c}\text { Crest } \\
\text { settlement (cms) }\end{array}$ \\
\hline $0.23 \mathrm{~g}$ & 7.0 & 3.59 & $18-23.4$ \\
$0.45 \mathrm{~g}$ & 8.5 & 28.8 & $521-782$ \\
\hline
\end{tabular}




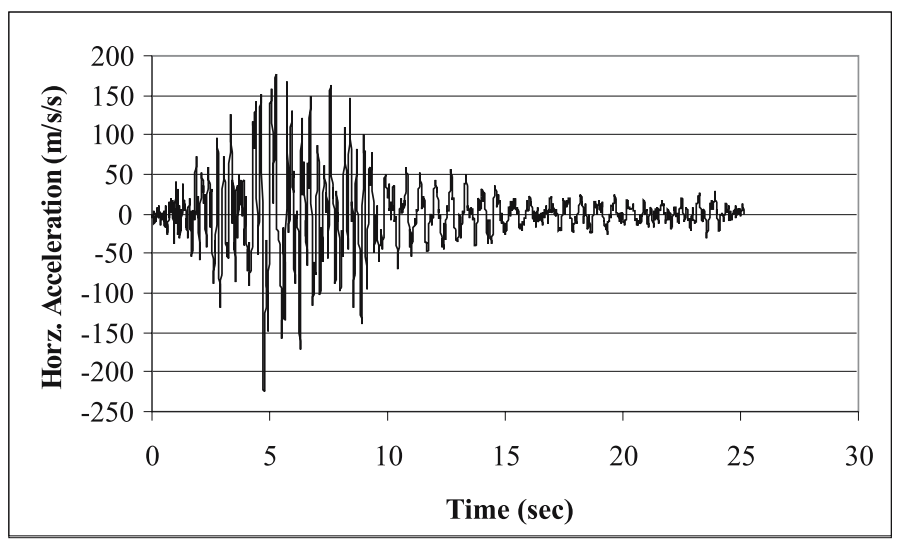

Figure 11. The selected ground motion scaled to $0.23 \mathrm{~g}$.

In this study, a finite element program called, PLAXIS (PLAXIS 2D, 2002) is utilized for the dynamic analyses of the Tehri dam. PLAXIS (version 8) is a commercial finite element package intended for the two-dimensional analysis in terms of deformation and stability in geotechnical engineering. PLAXIS is equipped with advanced features and material models to deal with various aspects of complex geotechnical problems. The steps required for the dynamic analysis in Plaxis are: construction of dam geometry, specifying material models for each zone of the dam and assigning materials parameters to the respective zones, mesh generation, applying boundary conditions, and defining steady state phreatic surface. The numerical analysis is done in three stages. In the first stage, the gravity force is turned on. In this stage the undrained behaviour of soil is ignored. In the next stage, the static analysis is done where the dam is built and the reservoir is impounded. In the third stage, the dynamic analysis is carried out. In this stage, acceleration time history of the selected earthquake is specified. The output in terms of acceleration, deformation, pore pressures and stresses are viewed at the end of each stage of analysis.

In absence of any reliable data on the acceleration time history for the region, the $23 \mathrm{sec}$ of the recorded ground motion of the 1985 Michoacan Mexico City Earthquake $\left(M_{w}=7 \cdot 6\right)$ was selected for this study. The ground motion was scaled to $0.23 \mathrm{~g}$ and $0.45 \mathrm{~g}$, and applied at the base of the dam to compute the permanent deformations of the dam during the earthquakes. Figure 11 shows the selected ground motion scaled to $0 \cdot 23 \mathrm{~g}$. The numerical analyses predicted

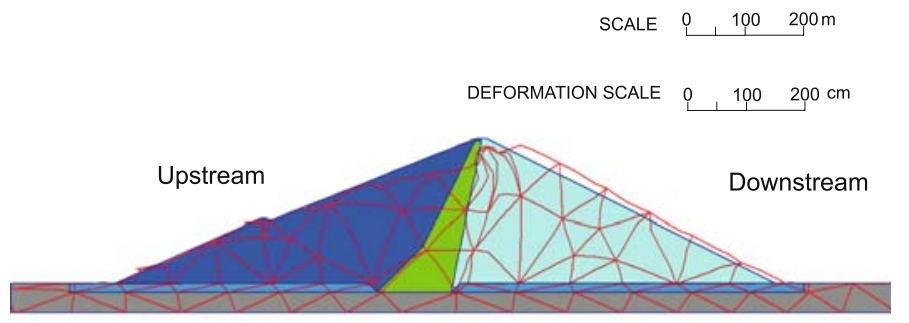

Figure 12. Deformation at the end of $23 \mathrm{sec}$ of $0.23 \mathrm{~g}$ earthquake motion (deformation magnified 100 times). 


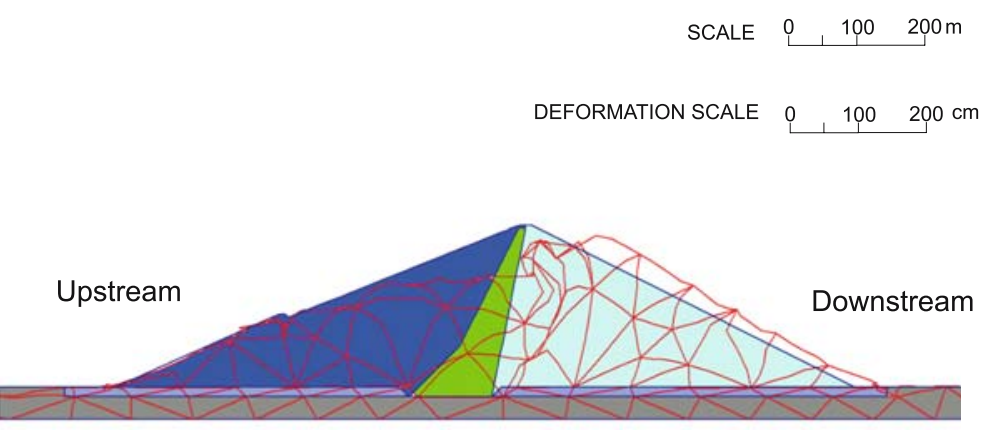

Figure 13. Deformation at the end of $23 \mathrm{sec}$ of $0.45 \mathrm{~g}$ earthquake motion (deformation magnified 100 times).

no liquefaction of the dam and its foundation during the earthquakes. Figures 12 and 13 show the deformed dam geometry at the end of $23 \mathrm{sec}$ of $0.23 \mathrm{~g}$ and $0.45 \mathrm{~g}$ earthquake motions, respectively. In both the figures deformations are magnified 100 times. The figures indicate that most of the deformations will be in the upper part of the upstream shell of the dam. For the $M_{w}=7$ earthquake the upstream face shall deform by $50 \mathrm{~cm}$ while for the $M_{w}=8.5$ event, it will deform by $110 \mathrm{~cm}$. The downstream shell shall deform by $20 \mathrm{~cm}$ and $51 \mathrm{~cm}$ for the $M_{w}=7$ and $M_{w}=8.5$ magnitude earthquakes. The vertical deformation was computed at the crest of the dam while horizontal deformation was obtained at the upstream berm of the dam for both the earthquakes. Figure 14 shows the vertical displacements at the crest of the dam for the $0.23 \mathrm{~g}$ and $0.45 \mathrm{~g}$ earthquakes. Figure 15 shows the horizontal displacements of the upstream berm of the dam for both the earthquakes. Since unusually large freeboard is maintained for this dam, in neither earthquake cases there will be overtopping of the dam. However for the $M_{w}=8.5$ theoretical event, there can be breaching of the upper portion of the filter/drain located by the side of the core which might cause uncontrollable seepage leading it to possible failure.

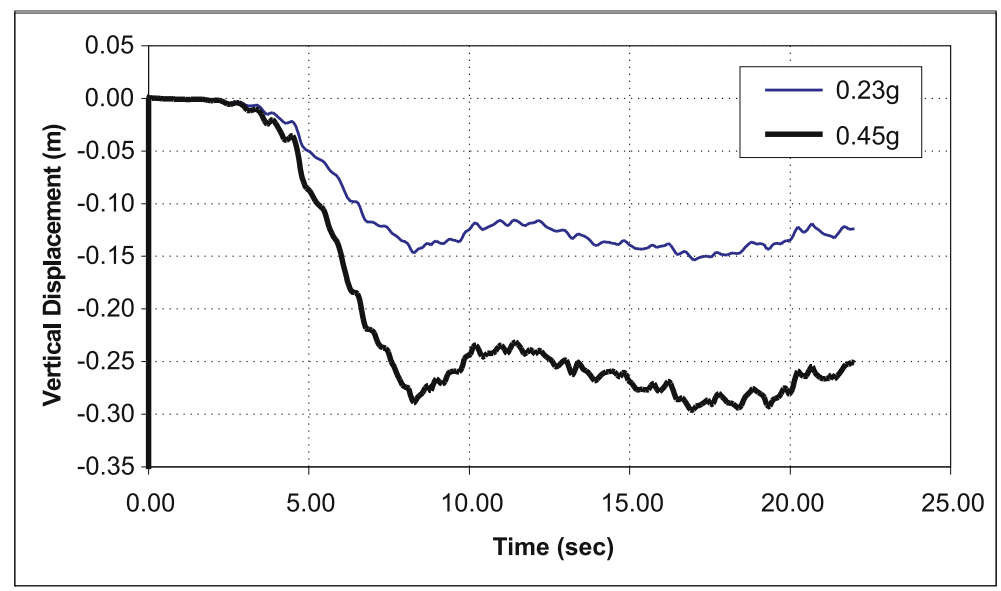

Figure 14. Vertical displacements at the crest of the dam. 


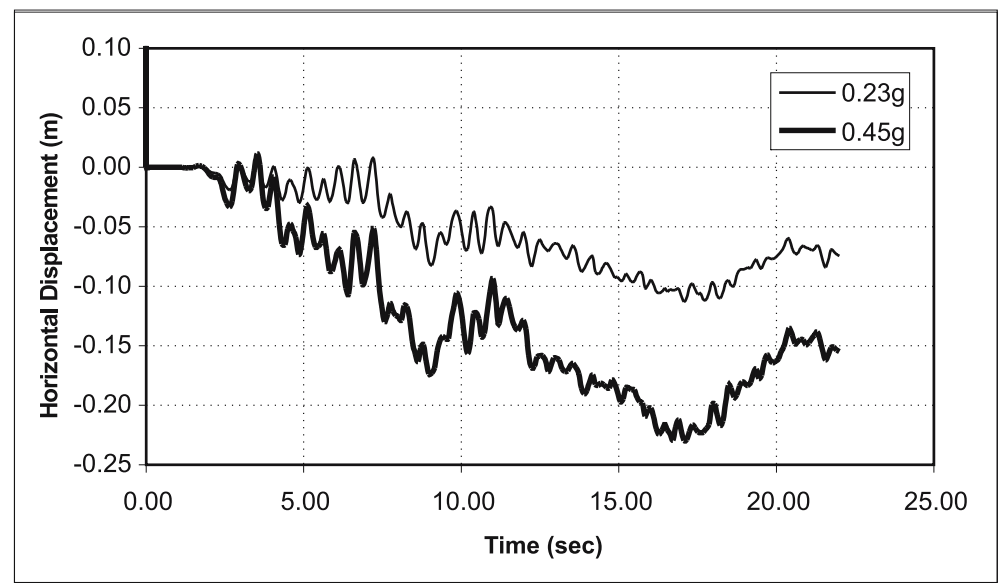

Figure 15. Horizontal displacements at the $U / S$ berm of the dam.

\section{Results}

Table 9 summarizes a comparison of the displacements of Tehri dam predicted by different empirical methods and a finite element method for $M_{w}=7.0$ and $M_{w}=8.5$ earthquakes. The results show a large variation, which is not surprising as the methods do not have any thing in common among them. Some of the statistical-based models are developed from completely different set of record. For the $M_{w}=7$ earthquake, the displacement of the upstream shell varies between $1.93 \mathrm{~cm}$ and $50 \mathrm{~cm}$. The displacement of the downstream shell varies between $2.45 \mathrm{~cm}$ and $42.68 \mathrm{~cm}$. The double integration method does not show any displacements for this case. For the $M_{w}=8.5$ hypothetical earthquake, the displacements vary between $11.35 \mathrm{~cm}$ and $566.53 \mathrm{~cm}$ for the upstream shell, and $14.13 \mathrm{~cm}$ to $782 \mathrm{~cm}$ for the downstream shell.

Thatte (1992) reported that plastic displacement for $M_{w}=7$ earthquake obtained by Seed's method was $17.37 \mathrm{~cm}$ and $48.25 \mathrm{~cm}$ for upstream and downstream slopes assuming the dam to be a rigid structure. The crest displacement was computed to be $52 \mathrm{~cm}$ when the dam was assumed to be non-rigid. Interestingly, these values are very close to the displacements obtained by the 2-D finite element method.

Table 9. Comparison of deformations predicted by different methods.

\begin{tabular}{|c|c|c|c|c|}
\hline \multirow[b]{2}{*}{ Methods used } & \multicolumn{2}{|c|}{ Deformations (cms) at $M_{w}=7 \cdot 0$} & \multicolumn{2}{|c|}{ Deformations (cms) at $M_{w}=8.5$} \\
\hline & Upstream & Downstream & Upstream & Downstream \\
\hline Seed \& Makadisi's & 27.44 & $42 \cdot 68$ & $566 \cdot 53$ & $755 \cdot 37$ \\
\hline Double integration & - & - & $52 \cdot 80$ & $147 \cdot 00$ \\
\hline Jansen & 1.93 & 2.45 & $11 \cdot 35$ & $14 \cdot 13$ \\
\hline Swaisgood & $8 \cdot 80$ & $8 \cdot 80$ & $112 \cdot 00$ & $112 \cdot 00$ \\
\hline Bureau & $18 \cdot 00$ & $23 \cdot 40$ & $521 \cdot 00$ & $782 \cdot 00$ \\
\hline Finite element & $50 \cdot 00$ & $20 \cdot 00$ & $110 \cdot 00$ & $51 \cdot 00$ \\
\hline
\end{tabular}


The large variation in the reported displacements of Tehri dam due to an earthquake indicates that the mechanism of failure in large rockfill dams may not be properly understood and more research is required in this area. The Tehri dam is located in a narrow canyon. Thus there is a possibility of magnification of acceleration through the dam due to the effect of canyon. This canyon effect has not been considered in the present study and should be looked at in near future.

\section{Conclusions}

- The present study indicates that the displacements due to an earthquake of magnitude $\left(M_{w}\right)$ 7.0 are significant but not enough to compromise the safety of Tehri dam.

- The displacements due to a hypothetical earthquake of magnitude $M_{w}=8.5$ are quite large. They might lead to a rupture in the existing $1 \mathrm{~m}$ thick filter zones, resulting in uncontrollable seepage.

- The 2-D finite element analyses show that the maximum deformations occur along the upper reaches of the upstream face of the dam while the surface at the foundation level has almost negligible deformations.

- For the $M_{w}=7$ earthquake, the maximum displacement is predicted by the finite element method, while for the $M_{w}=8.5$ earthquake, Seed and Makdisi's method predicts the maximum displacements.

- All the simplified methods predict larger displacements on the downstream face of the dam, but finite element method predicts almost two times larger displacements for the upstream face of the dam.

- Among the simplified methods, the maximum displacements are computed by Seed and Makdisi's method, while the minimum displacements are obtained by Jansen's method.

- The large variation of the seismic displacements predicted by different methods indicates scope for further research in this area and stresses on the need for the instrumentation of the dams and verification of different methods in predicting seismic displacements of dams. The different dams coming up in the Himalayan region should be properly instrumented to record ground motions, amplification of motions through the dam and displacements of the dam, so that better understanding of the seismic behaviours of large earth and rockfill dams can be achieved and proper mitigation measures can be put in place before hand in case a disaster strikes.

\section{References}

Abdel-Ghaffar A M, Scott R F 1978 An investigation of the dynamic characteristics of an earth dam, Report No. EERL 78-02, Earthquake Engineering Research Laboratory, California Institute of Technology, Pasadena, Calif

Abdel-Ghaffar A M, Scott R F 1979 Analysis of earth dam response to earthquakes. J. Geotech. Eng. Div. ASCE 105(12): 1379-1404

Ambraseys N, Bilham R 2000 A note on the kangra $M_{S}=7 \cdot 8$ earthquake of 4 April 1905. Current Science 79(1): 45-50

Ambraseys N, Jackson D 2003 A note on early earthquakes in northern india and southern tibet. Current Science 84(4): 570-582

Ambraseys N N, Sarma S K 1967 The response of earth dams to strong earthquakes. Geotechnique 17(9): 181-213 
Bilham R, Szeliga W 2008 Interaction between the himalaya and the flexed indian plate - Spatial fluctuations in seismic hazard in india in the past millennium? Seismic Engineering Conf. Comm. The 1908 Messina \& Reggio Calabria Earthquake, eds. A Santini, N Moraci, Am. Inst. of Physics Conf. Proc. 224-231

Bray J D, Travasarou T 2007 Simplified procedure for estimating earthquake-induced deviatoric slope displacements. J. Geotech. Eng. Div. ASCE 133(4): 381-392

Bureau G 1997 Evaluation methods and acceptability of seismic deformations in embankment dams. Proc. $19^{\text {th }}$ Cong. on Large Dams Florence, Italy 500-510

Elgamal A M, Abdel-Ghaffar A M 1987 Elasto-plastic seismic response of 3-D earth dams: applications. J. Geotech. Eng. Div. ASCE 113(11): 1309-1325

Elgamal A M, Scott R F, Succarieh M F, Yan L 1990 La Villita dam response during five earthquakes including permanent deformation. J. Geotech. Eng. Div. ASCE 116(10): 1443-1462

Feldl N, Bilham R 2006 Great himalayan earthquakes and the Tibetan plateau. Nature 444: 165-170

Finn W D L 1993 Seismic design considerations for dams in himalaya with references to Tehri dam. In: earthquake hazard and large dams in the himalaya, ed. V K Gaur, INTACH, New Delhi, 116-134

Gaur V K 1993 Earthquake Hazard and Large Dams in the Himalayas, INTACH, New Delhi

Gazetas G, Dakoulas P 1992 Seismic analysis and design of rockfill dams: State of the art. Soil Dynamics and Earthquake Eng. 11: 27-61

Gazetas G, Uddin N 1994 Permanent deformation on preexisting sliding surfaces in dams. J. Geotech. Eng. Div. ASCE 120(11): 2041-2060

High Level Committee of Experts 1990 Report on Safety Aspects of Tehri dam Project, Govt. of India Iyengar R N 1993 How safe is the proposed Tehri dam to earthquake. Current Science 65(5): 384-392

Jansen R B 1990 Estimation of embankment dam settlement caused by earthquake. Int. Water Power \& Dam Construction 42(12): 35-40

Khattri K N 1993 An overview of seismicity of himalaya, In: earthquake hazard and large dams in the himalaya, ed. V K Gaur, INTACH, New Delhi 35-62

Li H, Chi S, Lin G, Zhong H 2008 A modified approach for determination of nonlinear properties in seismic response analyses for $200 \mathrm{~m}$ high core rock-fill dams. Can. Geotech. J. 45(8): 1064-1072

Lin J S, Whitman R V 1983 Decoupling approximation to the evaluation of earthquake-induced plastic slip in earth dams. Earthquake Eng. and Struct. Dynamics 11: 667-678

Lin J S, Whitman R V 1986 Earthquake induced displacements of sliding block. J. Geotech. Eng. Div. ASCE 105(12): 1427-1434

Makdisi F I, Seed H B 1978 Simplified procedure for estimating dam and embankment earthquakeinduced deformations. J. Geotech. Eng. Div. ASCE 104(7): 849-867

Martin P P, Niznik J A, Sengupta A 1993 Prediction of static and dynamic deformation response of blue ridge dam, Georgia, USA, Int. Workshop on Dam Safety Evaluation, Switzerland

Martin P P, Sengupta A 1994 Numerical analysis of bath county upper reservoir dam. 3rd ICOLD Benchmark Workshop on Numerical Analysis of Dams (Theme B1), Paris (France), Sept. 29-30

Mejia L H, Seed H B 1983 Comparison of 2D and 3D dynamic analyses of earth dams. J. Geotech. Eng. Div. ASCE 109(11): 1383-1398

Mejia L H, Seed H B, Lysmer J 1982 Dynamic analysis of earth dam in three-dimensions. J. Geotech. Eng. Div. ASCE 108(12): 1586-1604

Newmark N M 1965 Effects of earthquakes on dams and embankments. Geotechnique 15(2): 139-159

Papalou A, Bielak J 2004 Nonlinear seismic response of earth dams with canyon interaction. J. Geotech. Eng. Div. ASCE 130(1): 103-110

Plaxis 2D-A Finite Element Code for Soil and Rock Analyses 2002 R B J Brinkgreve (eds), Version 8, Delft University of Technology \& Plaxis b.v., The Netherlands, A.A Balkema Publishers Lisse/bingdon/Exton(PA)/Tokyo

Prevost J H, Abdel-Ghaffar A M, Lacy S J 1985 Nonlinear dynamic analyses of an earth dam. J. Geotech. Eng. Div. ASCE 111(7): 882-897

Rajendran C P, Rajendran K 2005 The status of central seismic gap: A perspective based on the spatial and temporal aspects of the large himalayan earthquakes. Tectonophysics 395: 19-39 
Resendiz D, Romo M P 1982 El Infiernillo and La Villita dams: Seismic behaviour. J. Geotech. Eng. Div. ASCE 108(1): 109-130

Richter C F 1958 Elementary seismology, Freeman, San Francisco 764

Romo M P, Resendiz D 1981 Computed and observed deformation of two embankment dams during earthquake. Dams and Earthquakes, Thomas Telford Ltd, London 267-274

Sarma S K 1975 Seismic stability of earth dams and embankments. Geotechnique 25(4): 743-761

Seed H B 1966 A method for earthquake-resistant design of earth dams. J. Soil Mech. Found. Div. ASCE 92(1): 13-41

Seed H B 1973 Analysis of the Slides in the San Fernando Dams during the Earthquake of February 9, 1971, Report No. EERC 73-2, Earthquake Engineering Research Center, Univ. of California, Berkeley, Calif

Seed H B 1979 Consideration in the earthquake resistant design of earth and rockfill dams. Geotechnique 29(3): 234-249

Seed HB 1981 Lessons from the performance of earth dams during earthquake, Dams and Earthquakes, Thomas Telford Ltd (England) 97-104

Seed H B, Idriss I M 1971 A simplified procedure for evaluating soil liquefaction potential. J. Soil Mech. Found. Div. ASCE 97(9): 1249-1274

Seed H B, Lee K L, Idriss I M 1969 Analysis of the sheffield dam failure. J. Soil Mech. Found. Div. ASCE 95(6): 1453-1490

Seed H B, Martin G R 1966 The seismic coefficient in earth dam design. J. Soil Mech. Found. Div. ASCE 92(3): 25-58

Seed H B, Wong R T, Idriss I M, Tokimatsu K 1986 Moduli and damping factors for dynamic analysis of cohesionless soils. J. Geotech. Eng. Div. ASCE 112(11): 1016-1032

Sengupta A, Martin P P 1996 Prediction of the seismic response and deformations of a hydraulic fill dam. CHILECOLD 96, Santiago, Chile

Sengupta A, Martin P P 1997 Earthquake-induced permanent deformations in earth dams: From a challenge to practice, ICOLD 97, Madrid, Spain

Serff N, Seed H B, Makdisi F I, Chang C Y 1976 Earthquake induced deformations of earth dams, Report No. EERC 76-4, Earthquake Engineering Research Center, Univ. of California, Berkeley, Calif

Swaisgood J R 1995 Estimating deformation of embankment dams caused by earthquakes. ASDSO Western Regional Conf. Montana, USA 1-7

Thatte C D 1992 Earthquakes, Dam design and Tehri project. J. Ind. Geot. 22(1): 1-41

THDC 1990 A seismic design of Tehri dam, A Report submitted by Tehri Hydro Development Corporation Ltd.

USBR 1989 Seismic design and analysis of embankment dams, Design Standards, Chapter 13, DS13(13)-7, United States Department of the Interior, Bureau of Reclamation, Denver, Colorado

Vrymoed J 1981 Dynamic FEM model of Oroville dam. J. Geotech. Eng. Div. ASCE 107(8): 1057-1077

Yan Liping 1991 Seismic deformation analysis of earth dams: A Simplified Method, Report No. SML 91-01, Soil Mechanics Laboratory, California Institute of Technology, Pasadena, Calif

Zienkiewicz O C, Leung K H, Hinton E 1980 Earth dam analysis for earthquakes: Numerical solutions and constitutive relations for nonlinear (damage) analysis, Design of Dams to Resist Earthquake, ICE, London 141-156 